\title{
DYNAMICS OF DEPRESSION AMONG ADOLESCENTS IN SECONDARY SCHOOLS IN BULGARIA
}

\author{
Stanislava Stoyanova, Venka Petrova \\ South-West University "Neofit Rilski", Blagoevgrad, Bulgaria \\ E-mail: avka@abv.bg, veni19@abv.bg
}

\begin{abstract}
Depression becomes more and more typical for adolescence. The study of dynamics of depression during the teenage years is important for differentiation of the most vulnerable periods for development of depression in this age and to be pointed out some factors that could contribute to triggering, preventing or recovering depression. This study of dynamics of depression was based on Developmental theories of dynamics of depression that relate depression to some vulnerable age groups and on the theories that relate dynamics of depression to one or more factors that trigger depression in different stages of human life. Depression in Bulgarian high-school students was compared at the beginning and at the end of the school year in a longitudinal study. 360 Bulgarian secondary school students from $9^{\text {th }}$ to $12^{\text {th }}$ grade were studied twice - at the beginning of the school year 2013/2014 and at the end of this school year. Several methods were used - Zung Self-Rating Depression Scale, Zung Self-Rating Anxiety Scale, and Eysenck Personality Questionnaire. A model of dynamics of depression at upper school age in Bulgaria has been suggested. According to this model, depression slightly increases from the beginning to the end of the school year being differentiated by the types of the schools at the beginning of the school year and by the interaction of the types of schools, gender and grade at the end of the school year. Some of its correlates (anxiety, extraversion/introversion, neuroticism, and psychoticism) and social determinants (gender, school grade, and types of schools) were found. The interventions focused on diminishing anxiety, neuroticism (for example by meeting students' expectancies) and psychoticism (developing empathy and altruism), and increasing extraversion (better communication, social support) could be effective for diminishing depression throughout the whole school year. Motivating students for participating in more extra-curriculum activities related to the students 'plans for further realisation in universities and workplace would be useful for diminishing students'depression as the experience of special education schools indicate.
\end{abstract}

Key words: adolescents, anxiety, depression, introversion, longitudinal study, neuroticism, psychoticism.

\section{Introduction}

Depression is an affective disorder that becomes more and more widespread among different populations in different regions and in different age groups. One person could suffer from depression several times in his/her life. It is important to try to find out if there are some patterns of development and dynamics of depression during ontogenesis. The focus of this study is adolescent age when people are vulnerable to many stress factors because of upcoming changes in their biological 
and social functioning that provoke different psychological responses. Depression could be among the inadequate mental reactions to some internal and external factors.

Depression is among the phenomena that are clearly defined and whose nature is almost undoubted, but whose etiology and dynamics are not enough known.

\section{Definition and Symptoms of Depression}

Depression is a kind of mood disorder characterized by at least 2 weeks of depressed mood and loss of interest accompanied by some additional symptoms, different in number and content for each type of depressive disorders: unipolar - major, dysthymic, not otherwise specified; or as a part of bipolar disorders (American Psychiatric Association, 1994, pp.317-318); mild, moderate, severe, unspecified, recurrent, etc. (World Health Organization, 1992, p.100).

The additional symptoms of depression could be increased by tiredness, diminished activity, reduced concentration, reduced self-esteem, ideas of guilt and unworthiness, pessimistic views of the future, suicide ideas, disturbed sleep, etc. (World Health Organization, 1992, p.100). Other symptoms of depression are negative attitudes, performance difficulty and somatic elements, such as increases as well as decreases in appetite and sleep during the past two weeks (Whisman et al., 2012), sad mood, hopelessness, weight change, retardation, and anxiety (Leserman \& Koch, 1993, p. 538). Hopelessness is typical for severe depression (Min, 2002).

Dynamics of depression is characterised by slow accumulation of more and more depressive symptoms as a reaction to some environmental and biological factors.

\section{Risk Factors for Depression}

Risk factors have their crucial importance for the onset of depression. They could trigger depression and delay the recovery.

Depression could be provoked by some important personal and/or social events. $44.8 \%$ of 373 Chinese adolescents from grades 7-9 had symptoms of depression 3 years after an earthquake (Pan et al., 2013). Unhappy childhood increases depression (Joules, Williams \& Thompson, 2014).

Some social - economic factors are potential triggers for depression. Children and young people from low-income households or from families of high socioeconomic statuses, from ethnic minority groups, from rural communities and from affluent families are potentially more vulnerable to symptoms of depression (Joe, Joe \& Rowley, 2009). Low financial status was related to both susceptibility to depression and suicidal thoughts (Mojs, Warchol-Biederman \& Samborski, 2012).

Asian-specific risk factor for depression is being foreign-born (Song et al., 2011) that indicates some difficulties in one's adaptation, strong support of in-group cultural traditions and possible perception as being rejected by the other population.

The predictors of first- to sixth-grade Korean pupils' depression were living in a disadvantaged neighbourhood (Lee et al., 2012).

There are some cross-cultural differences in depression. The adults in six countries had a common symptom of depression - despair. Depression was higher in former Czechoslovakia, followed by Sweden, Germany, Spain, England, and USA (Zung, 1972). Some other findings also rank the nationalities concerning the experienced depression. Susceptibility to depression was higher among students living in former Eastern bloc countries than in Western Europe (Mikolajczyk et al., 2008).

Hispanic teen students report more depression than Whites and African Americans (RoblesPina, Defrance \& Cox, 2008). Asian students from 9th to 12th grades had a higher prevalence of depressed symptoms compared to their peers from other ethnic and national background (Song et al., 2011). About 20 million Americans suffer from depression each year (in Mental Health America, 2013). 25\% of Australian students using Facebook were identified as at-risk for depression (Skues, Banagan \& Wise, 2014).

Other risk factors for depression are related to school. Early school retention increases the risk of adolescent depression. Retained students versus non-retained students have lower self-concept, lower grade points (school success) and higher levels of depression (Robles-Pina, Defrance \& 
OF PSYCHOLOGY

IN THE $21^{\text {st }}$ CENTURY Vol. 9, No. 1, 2015

Cox, 2008). School absenteeism, inability to remain focused and complete schoolwork in a timely manner could be related to depressive moods (Joe, Joe, \& Rowley, 2009).

The predictors of first- to sixth-grade Korean boys' depression were perceived less enjoyable school life and worse peer relations in school (Lee et al., 2012). Chinese high school students from Hong Kong from 14 to 21 years old who were perfectionists had higher satisfaction with life and lower depression than non-perfectionists (Wang, Yuen \& Slaney, 2009).

Some risk factors for depression are related to lifestyle and habits. Smoking and injury are major risk factors for depressed mood among Asians and Caucasian teen students (Song et al., 2011). Maladaptive coping is a risk factor for depression (Thorsteinsson, Ryan \& Sveinbjornsdottir, 2013). Life style characterized by fears, anxiety, passiveness, learned helplessness, lack of realization of own limits and turn for overload diminishes frustration toleration and facilitates depression (Horney, 1997).

Depression could be related to health status, some illnesses. For example, adolescents with allergies are at risk for experiencing higher rates of depressive and anxious symptoms than healthy adolescents (Molzon et al., 2011). Overweight increases risk for depression in adolescence (Joe, Joe \& Rowley, 2009). Poor physical health increases depression (Joules, Williams \& Thompson, 2014).

Young people face elevated risk of depression living with a parent experiencing chronic or acute illnesses (Morley \& Jenkinson, 2012).

A part of the risk factors for depression are related to some peculiarities of social relationships. Adolescents had more depressive symptoms if their mothers experienced trauma and parented with an authoritarian style (Leslie \& Cook, 2015). Children with depressive parents feel guilty of having caused their parents' mood because of one's imperfection (Riemann, 1961). Mothers' rumination was related to higher depression of their children - adolescents in Iran (Jafari, Yousefi \& Manshaee, 2014). Family dysfunction or extreme care and concern from parents about children's study and their academic performance, higher academic pressure, poor relationship with others, negative self-perception (Huang et al., 2009), and lack of social support (Thorsteinsson, Ryan \& Sveinbjornsdottir, 2013) are among the risk factors for depression in adolescents.

Asian individuals perceive receiving more maladaptive inferential feedback (not helping a person to change his/her negative behaviours) from friends and family members than Caucasians and African Americans that may facilitate depression (DeFronzo Dobkin et al., 2007). Depression was higher among lonely Chinese students (Running, Ligon \& Miskioglu, 1999).

Some personality characteristics make people more vulnerable for depression. Perceived stress at school, at work is a risk factor for depression (Lee et al., 2012; Thorsteinsson, Ryan \& Sveinbjornsdottir, 2013; Joules, Williams \& Thompson, 2014). Anxiety was among the predictor of first- to sixth-grade Korean pupils' depression (Lee et al., 2012).

Depression is higher among Chinese students with low self-esteem (Running, Ligon \& Miskioglu, 1999). Depression is related to self-appraisal - negative self-judgment of dysfunctional beliefs (such as: I am a born loser; I am nothing if a person I love doesn't love me) and low explicit self-esteem (Phillips \& Hine, 2012). Low self-concept (evaluative statements that students make of themselves in particular areas, such as academic performance, physical appearance, social interactions and athletic performance) is associated with higher depression (Robles-Pina, Defrance $\&$ Cox, 2008). Self-blame and rumination were related with high levels of anxiety and depression (Omran, 2011)

\section{Theories of Dynamics of Depression}

\section{Some Theories Relate Dynamics of Depression to One or More Factors that Trigger Depression in Different Stages of Human Life}

The evolutionist or Darwinian view of dynamics of depression (Price, 2009) divides the population into selected and non-selected - as sexual partners, territorial owners, etc. Once selected, a person may later be de-selected. Depression has evolved for those in the social role of being unselected and de-selected who enabled being unselected to contribute negatively to their social 
well-being (Price, 2009). According to the evolutionist view, depression could be possible at every time of human life after feeling unselected or de-selected and its dynamics could be predicted on the basis of competitions one participates in.

Social ranking theory of depression (Storck, 1999) considers that depression follows submission and withdrawal.

Psychosocial class theory of depression (Storck, 1999) deals with depression as typical for lower, under middle social classes caused by lack of resources, illness and instability. Higher depression is associated with poor socio-economic conditions (Mozumdar \& Roy, 2010). Disability statuses are related to change in depressive symptoms. Stable disability statuses increase depression. The onset of disability stronger changes depressive mood than recovery from disability (Yang \& George, 2005).

Some studies on dynamics of depression relate it to childbirth and marital satisfaction. Married couples in Finland (mean age about 30 years old) typically have similar levels of depressive symptoms and a similar pattern of changes in depression in the period before child birth (3rd month of pregnancy) and after child birth (till the child was about 2 years old). Spouses mutually influence each other with respect to their mood. They share some attributions and some life situations. Spouses with a higher level of depressive symptoms were more likely to show a greater decrease in them after the birth of the child when compared with those who originally reported fewer depressive symptoms. The birth of a child could be motivating, leading to new and meaningful activities. It may reduce some previously stressful factors, such as heavy workload. A high level of depressive symptoms among the couples was associated with a low level of marital satisfaction (Salmela-Aro et al., 2006).

The final stage of dynamics of depression is self-harm and committing suicide (Millard, 2013).

\section{Psycho-Social Theories of Dynamics of Depression Deal with the Stages of Psycho-Sexual Development}

The young child recognizes the mother as the basic source of satisfaction of its needs and the child realizes its dependency on his/her mother. If the mother is perceived as present and loving, the sense of own importance is formed. Unstable mother's presence is related to a negative attitude towards oneself, because of the lack of confidence that this individual is worthy of being loved. This early experience leads to a future sense of inferiority (Adler, 1997). Parent's hyperprotection also causes child's low self-confidence, because the child cannot express oneself, neither become independent. When the sense of inferiority is strongly expressed, it could be followed by the idea to live for the benefit of other people and to feel guilty when satisfying own needs. This is the beginning of formation of individual depressive position that is accompanied by the fear of independent existence without feeling the contact with the referent adult; dependency; the fear of assertive and aggressive manifestations (Riemann, 1961).

Klein described 'depressive' position in the infant's development in relation to separation with mother's breast after feeding. Later baby begins to integrate its fragmented perceptions of its parents and has a more integrated sense of self. Ambivalent feelings (hateful feelings about the loved object, prototypically the mother) lead to the sense of guilt. The term 'depressive position' refers to the experience, at any stage of life, of guilt and grief varying from normal mourning for loss to severe depression (Klein, 1940).

Ego-state of depressive personality hates his/her Id-state that provokes the feeling of being unworthy and despair (Klein, 1935).

The defence mechanisms of introjections and projection of aggression and anxiety provoke fear of persecution that is the starting point of the following stage of dynamics of depression - the manic position (Klein, 1940) called also the paranoid position (Klein, 1935). Depression is related to sadness for the lost loved object. Manic position is related to defences from the bad persecuting objects and it could result in a feeling of triumph related to considering oneself almighty and despising others. Normal development fluctuates between depressive and manic positions (Klein, 1940).

Depression could be overcome by means of feeling safety, following after internal recover- 
OF PSYCHOLOGY IN THE $21^{\text {st }}$ CENTURY Vol. 9, No. 1, 2015

ing of the image of good parents, of a recently lost person, and own internal peaceful mental life that had been disintegrated and vulnerable. A manic person had not been able to establish internal good, positive objects in his/her early childhood (Klein, 1940).

Paranoid position in dynamics of depression is characterized by means of introjection of a whole and real object, but paranoid personality failed to fully identify with this object or to maintain one's identification with this object, because of high anxiety and fear of persecution (Klein, 1935).

The difficulties in establishing relationships with referent adults in childhood are followed by such problems in the future, fear of being abandoned and risk for depression (Riemann, 1961; Horney, 2002).

Depressive personality could develop further sensitivity to the needs of other family members and finding life meaning in solving emotional conflicts in family (McWilliams, 2011).

Depressive personality directs aggression to oneself in order to escape from denunciation as unworthy of being loved. Defense mechanisms unconsciously form negative automatic thoughts (based on logical errors, overgeneralization, etc.) that are among the basic factors for depression. Wrong way of thinking deepens depression (Beck et al., 2003).

Development of personal depression maintains the idea of being guilty of all negative life events. Depressive people are sensitive to criticism and emotionally vulnerable. They could diminish their depression and guilt taking care of others, being altruistic (Riemann, 1961).

\section{Developmental Theories of Dynamics of Depression Relate Depression to Some Vulnerable Age Groups}

Depression affects all age ranges, especially the elderly and children (Wehner \& Stoner, 2001). There are some data for prevalence of depression among high schools students in different countries. Major depressive disorder is now one of the most widespread among adolescents with the first depressive episode in late childhood or early adolescence (Shavers, 2014). Early childhood depression increases the risk of adolescent depression (Robles-Pina, Defrance \& Cox, 2008).

About $11 \%$ of adolescents in USA have a depressive disorder by age 18 (Allison et al., 2013). $24 \%$ of the last-year high schools students in Laos were depressed (Phanthavong, Naphayvong $\&$ Reinharz, 2013). From 33\% to about 38\% of adolescent Facebook users (more females than males) had some form of depression (Moreno, Jelenchick \& Kota, 2013).

About 100 Bulgarian high school students in Sofia from $8^{\text {th }}$ to $11^{\text {th }}$ grades were studied twice in 1996 and 1998 as a longitudinal study - in 1996 they were in $8^{\text {th }}$ and $9^{\text {th }}$ grades, in 1998 they were in $10^{\text {th }}$ and $11^{\text {th }}$ grades. About 300 different students from $8^{\text {th }}$ to $11^{\text {th }}$ grades were studied as a cohort study in each of these years. Their levels of depression were stable (Botcheva, Feldman \& Leiderman, 2002).

The pupils studying at the secondary schools had higher depression scores than those studying at the primary schools in China (Running, Ligon \& Miskioglu, 1999). School age children are ten times more likely to experience depression in their lifetime than three decades ago (Robles-Pina, Defrance \& Cox, 2008). Moderate and severe depression were more frequent in the age groups of 21-40 years old, but mild depression was more typical for 41-60 years old Nigerians (Shittu et al., 2002). Depression is more typical for the people advanced in age - 50 years old and above (Wood et al., 2010; Büchtemann et al., 2012; Bose \& Neelakandan, 2013) than for the young people (Patten, Gordon-Brown, \& Meadows, 2010; Wood et al., 2010; Cole et al., 2012; Tezvaran, Akan, \& Zahmaciog, 2012).

Hispanics aged 51 and older started with worse depressive symptomatology, but had a greater rate of reduction in depressive symptoms within 11 years compared to Black and White Americans. Middle-aged Black Americans had a higher level of depressive symptoms compared to White Americans, but experienced a lower rate of increase over time (Xu et al., 2010).

Research on dynamics of depression among different populations in different countries revealed the trend depression to increase again in old age, above 60 years old.

$57.8 \%$ of elderly people in Nepal suffered from some form of depression, mainly lonely women dependent on others for daily activities (Chalise, 2014). 49.8\% of the elderly patients with multimorbidities suffered from depression in South Africa (Stanners et al., 2013). 
Depression may worsen over a period of time and it is commonly comorbid with a chronic disease. Depression produces one of the greatest decrements in human health when compared to other chronic conditions (Shafi \& Shafi, 2014).

Dynamics of depression was studied among some occupational groups like physicians. Depression increased irregularly from the beginning to the end of each intern year. Depression frequency diminished from the first to the third year of internship among resident physicians (Joules, Williams \& Thompson, 2014).

When asked to think their nearest future, depressed individuals expected ambivalent or negative cognitive, emotional, physical and socioeconomic consequences, but these negative consequences were reduced in strength concerning the more distant future (Sarkohi et al., 2013).

\section{Rationale of the Study}

There are some research findings that indicate that depression becomes more and more typical for adolescence (Robles-Pina, Defrance \& Cox, 2008; Shavers, 2014). It is important to be distinguished the different stages in dynamics of depression during the teenage years in order to be specified the most vulnerable periods for development of depression in this age and to be pointed out some factors that could contribute to triggering, preventing or recovering depression.

The objectives of the study were to be selected several types of schools and respectively - the secondary school students from $9^{\text {th }}$ to 12 the grades to be contacted, as well as their parents and school principals, school psychologists and some teachers, in order to be received their informed consent for students' participation in the study. Then - to be studied depression, anxiety, extraversion/introversion, neuroticism, and psychoticism at the beginning of school year, as well as and social desirability as an indicator of sincere self-report and striving for approval. At the end of the school year this process was repeated again in each grade. The results from two measurements were compared reflecting the effect of school education, workload at school on dynamics of depression, and the correlation between depression and some personality and socio-demographic characteristics.

The aim of the study was to be compared depression in Bulgarian high - school students at the beginning and at the end of the school year, and to be found some of its correlates (anxiety, extraversion/introversion, neuroticism, psychoticism, and social desirability) and social determinants (gender, age, school grade, and types of schools), to try to specify the effect of school education and workload at school on dynamics of depression.

One hypothesis of the study was that depressive symptoms at the end of the school year would be more strongly expressed than at the beginning of the school year, because of more school workload at the end of the school year.

Another hypothesis supposed that depression would be higher among more anxious students, introverts, with higher neuroticism, higher social desirability and lower psychoticism. The third hypothesis supposed the existence of some differences in students' depression levels depending on the grades and types of schools.

\section{Methodology of Research}

\section{General Background of the Research}

Longitudinal research on dynamics of depression was conducted at the beginning and at the end of school year 2013/2014 in each grade from $9^{\text {th }}$ to $12^{\text {th }}$. Comparisons were made between several age groups of Bulgarian adolescents differing in their gender, grade, types of schools and some personality characteristics - introversion/extraversion, neuroticism, anxiety, and psychoticism. These personality characteristics were chosen because they were stable; anxiety often comorbided depression (Altin et al., 2014); and the appropriate methods for their measurement were available and standardized in Bulgaria. 
OF PSYCHOLOGY IN THE $21^{\text {st }}$ CENTURY Vol. 9, No. 1, 2015

\section{Sample}

The number of secondary school students from $9^{\text {th }}$ to $12^{\text {th }}$ grades in school year 2013/2014 was 6744 in Blagoevgrad, and 43281 in South-Western region of Bulgaria, and 132731 for the whole country (National Statistical Institute of Republic of Bulgaria, 2014).

The needed sample size for a representative community study for secondary school students in Blagoevgrad was 257 (confidence interval 6; confidence level 95\%), and for a representative community study for secondary school students in South-Western region of Bulgaria was 265 (confidence interval 6; confidence level 95\%), and for a representative study for secondary school students for the whole country was 266 (confidence interval 6; confidence level 95\%), that was computed by means of an online sample size calculator (Creative Research Systems, 2012).

360 secondary school students were studied twice in Blagoevgrad, South-Western part of Bulgaria - at the beginning of the school year 2013/2014 (September-October) and at the end of the school year 2013/2014 (May-June). They participated voluntarily. Informed consents from their parents were received. The school principals also approved conducting this study.

The study was conducted in five schools selected randomly from the list of schools in the region. At the beginning of the school year, they were from 14 to 19 years old. Their mean age was 16.5 years old, $\mathrm{SD}=1.1$ year. At the end of the school year, they were from 15 to 19 years old. Their mean age was 17 years old, $\mathrm{SD}=1.2$ year.

90 students studied at $9^{\text {th }}$ grade. 94 students studied at $10^{\text {th }}$ grade. 101 students studied at $11^{\text {th }}$ grade. 75 students studied at $12^{\text {th }}$ grade. 205 studied at schools of special education such as language schools and natural sciences and mathematics schools. 155 studied at schools of general education. 167 were boys and 193 were girls. A detailed distribution of social - demographic characteristics of the participants in the study is shown in Table 1.

Table 1. Frequency distribution of the secondary school students, according to types of schools, gender and grade.

\begin{tabular}{|c|c|c|c|c|c|c|c|}
\hline \multicolumn{3}{|c|}{ Types of schools } & \multicolumn{4}{|c|}{ Grade } & \multirow{2}{*}{ Total number } \\
\hline & & & 9 & 10 & 11 & 12 & \\
\hline \multirow{3}{*}{ Schools of special education } & \multirow{2}{*}{ Gender } & Male & 29 & 16 & 18 & 22 & 85 \\
\hline & & Female & 18 & 40 & 35 & 27 & 120 \\
\hline & \multicolumn{2}{|c|}{ Total number } & 47 & 56 & 53 & 49 & 205 \\
\hline \multirow{3}{*}{ Schools of general education } & \multirow{2}{*}{ Gender } & Male & 21 & 16 & 33 & 12 & 82 \\
\hline & & Female & 22 & 22 & 15 & 14 & 73 \\
\hline & \multicolumn{2}{|c|}{ Total number } & 43 & 38 & 48 & 26 & 155 \\
\hline
\end{tabular}

Johanson \& Brooks (2010) recommended at least 12 participants in a group to be studied as it was the case with the group with the fewest number of members in Table 1.

\section{Instruments}

The Bulgarian version of Zung Self-Rating Depression Scale - SDS (Kokoshkarova, 1984) was used twice - at the beginning of the school year 2013/2014 and at the end of the school year 2013/2014. It has 20 items regarding past 1-2 weeks answered on a 4-point scale. The scores on items were summed, divided by 80 and multiplied by 100 to yield scores ranging from 25-100. Scores were categorized as follows: raw score $<40$ or SDS index $<50$ - normal; raw score 41-47 or SDS index 50-59 - mild depression; raw score 48-55 or SDS index 60-69 - moderate depression; raw score $>56$ or SDS index $>70$ - severe depression (Kokoshkarova, 1984, pp.53, 59; Leserman \& Koch, 1993). Its Cronbach's alpha reliability varies from .7 to .92 in different samples (Leserman $\&$ Koch, 1993). In this Bulgarian sample of adolescents, its Cronbach's alpha= .697. 
Zung Self-Rating Depression Scale showed accuracy in identifying nondepressed individuals measure severity of symptoms is doubtful. SDS is not to very sensitive to change after treatment (Leserman \& Koch, 1993). The Zung Self-Rating Depression Scale is appropriate for screening large population (Wehner \& Stoner, 2001).

The Bulgarian version of Zung Self-rating Anxiety Scale - SAS (Kokoshkarova, 1984) was used twice - at the beginning of the school year 2013/2014 and at the end of the school year 2013/2014. It contains 4 affective and 15 somatic symptoms of anxiety and fear. The scores on items were summed, divided by 80 and multiplied by 100. A SAS index above 45 means expressed anxiety and fear (Kokoshkarova, 1984, p.64). In our sample, its Cronbach's alpha=.673.

The Bulgarian version (Paspalanov, Shtetinski \& Eysenck, 1984) of Eysenck Personality Questionnaire was used twice - at the beginning of the school year 2013/2014 and at the end of the school year 2013/2014. Cronbach's alpha of all its scales varied between .68 to .84 (Paspalanov, Shtetinski \& Eysenck, 1984, p.287). In our sample, Cronbach's alpha of EPQ varied from .613 for Social desirability, .717 for Extraversion/Introversion, .724 for Psychoticism, to .838 for Neuroticism.

EPQ was used to be found some correlations between extraversion, neuroticism, psychoticism, social desirability on the one hand, and depression on the other hand.

\section{Data Analysis}

Data were statistically processed by means of SPSS 16.0 using descriptive statistics, PairedSample T- Test, chi - square analysis, ANOVA, Pearson correlation, General linear model - Univariate analysis of variance, and Linear Regression (Method Enter).

\section{Results of Research}

Most students had depression scores in norm (see Table 2).

Table 2. Frequency distribution of levels of depression.

\begin{tabular}{ccccc}
\hline \multirow{2}{*}{$\begin{array}{c}\text { Levels of } \\
\text { depression }\end{array}$} & \multicolumn{2}{c}{ Beginning of the school year 2013/2014 } & \multicolumn{2}{c}{ End of the school year 2013/2014 } \\
\cline { 2 - 5 } & Frequency & Percent & Frequency & Percent \\
\hline Norm & 241 & 66.9 & 243 & 67.5 \\
Mild depression & 85 & 23.6 & 80 & 22.2 \\
Moderate depression & 24 & 6.7 & 29 & 8.1 \\
Severe depression & 10 & 2.8 & 8 & 2.2 \\
\hline
\end{tabular}

The secondary school students with some form of depression were about $30 \%$ of total number of studied students.

There were not any significant differences $\left(\mathrm{t}_{1359}=0.632 ; \mathrm{p}=.528\right)$ between secondary school students' depression at the beginning $(\mathrm{M}=38.76 ; \mathrm{SD}=6.7)$ and at the end of the school year $(\mathrm{M}=38.92 ; \mathrm{SD}=6.74)$. 
OF PSYCHOLOGY

IN THE $21^{\text {st }}$ CENTURY

Vol. 9, No. 1, 2015

Table 3. Crosstabs of levels of depression at the beginning and at the end of the school year.

Levels of depression at the end of the school year

\begin{tabular}{ccccccc}
\cline { 3 - 6 } & & Norm & $\begin{array}{c}\text { Mild } \\
\text { depression }\end{array}$ & $\begin{array}{c}\text { Moderate } \\
\text { depression }\end{array}$ & $\begin{array}{c}\text { Severe } \\
\text { depression }\end{array}$ \\
\hline $\begin{array}{c}\text { Levels of } \\
\text { depression at the }\end{array}$ & Mild depression & $\mathrm{N}$ & 16 & 64 & 3 & 3 \\
$\begin{array}{c}\text { begining of the } \\
\text { school year }\end{array}$ & Moderate depression & $\mathrm{N}$ & 3 & 3 & 18 & 0 \\
& Severe depression & $\mathrm{N}$ & 1 & 1 & 3 & 0 \\
\hline
\end{tabular}

Most students had the same level of depression at the beginning and at the end of the school year $(\mathrm{r}=.75 ; \mathrm{p}<.001)$, but the variance was higher among the depressed students than among the students in norm (see Table 3; $\chi_{9 \mid}{ }^{2}=46.96 ; \mathrm{p}<.001$; Cramer's $\mathrm{V}=.752$ ).

There were not any significant gender differences in the secondary students' depression at the beginning $(\mathrm{t}|358|=0.64 ; \mathrm{p}=.522)$ and at the end of the school year $(\mathrm{t}|358|=0.894 ; \mathrm{p}=.372)$.

There were not any significant differences in their depression between the students in different grades $(9,10,11$ and 12$)$ at the beginning $\left(\mathrm{F}_{|3,356|}=1.08 ; \mathrm{p}=.358\right)$ and at the end of the school year $\left(\mathrm{F}_{|3,356|}=1.22 ; \mathrm{p}=.302\right)$.

Table 4. Differences between types of schools in students' depression.

\begin{tabular}{clccccc}
\hline & & $\mathbf{N}$ & $\mathbf{M}$ & $\mathbf{S D}$ & $\mathbf{F}_{|1,358|}$ & $\mathbf{p}$ \\
\hline $\begin{array}{c}\text { Depression at the beginning of the } \\
\text { school year }\end{array}$ & Schools of special education & 205 & 38.12 & 6.94 & & \\
& Schools of general education & 155 & 39.6 & 6.3 & 4.333 & .038 \\
\hline \multirow{2}{*}{$\begin{array}{c}\text { Depression at the end of the } \\
\text { school year }\end{array}$} & Schools of special education & 205 & 38.36 & 7.1 & \multirow{2}{*}{3.253} & .072 \\
\hline
\end{tabular}

The students at secondary schools of general education were more depressed at the beginning of the school year than the students at schools of special education, but there were not any significant differences in students' depression between the types of schools at the end of the school year (see Table 4).

Table 5. Differences between types of schools in students' levels of depression at the beginning of the school year.

Levels of depression

\begin{tabular}{ccccccc}
\cline { 3 - 6 } & & Norm & $\begin{array}{c}\text { Mild } \\
\text { depression }\end{array}$ & $\begin{array}{c}\text { Moderate } \\
\text { depression }\end{array}$ & $\begin{array}{c}\text { Severe } \\
\text { depression }\end{array}$ \\
\hline \multirow{3}{*}{$\begin{array}{c}\text { Types of } \\
\text { schools }\end{array}$} & $\begin{array}{c}\text { Schools of special } \\
\text { education }\end{array}$ & $\mathrm{N}$ & 149 & 37 & 12 & 7 \\
\cline { 2 - 6 } & $\begin{array}{c}\text { \% within schools of } \\
\text { special education }\end{array}$ & 72.7 & 18 & 5.9 & 3.4 \\
\cline { 2 - 6 } & $\begin{array}{c}\text { Schools of general } \\
\text { education }\end{array}$ & $\begin{array}{c}\text { \% schools of general } \\
\text { education }\end{array}$ & 59.4 & 31 & 78 & 3 \\
\hline
\end{tabular}

More students at schools of general education had mild depression than the students at schools of special education $\left(\chi_{3 \mid}{ }^{2}=9.748 ; \mathrm{p}=.021\right.$; Cramer's $\left.\mathrm{V}=.165\right)$ at the beginning of the school year (see Table 5). 
Table 6. General linear model of influence of gender, grade, age, and types of Vol. 9, No. 1, 2015 schools on students' depression at the beginning of the school year (main effects and interactions).

\begin{tabular}{lcccccc}
\hline \multicolumn{1}{c}{ Source } & $\begin{array}{c}\text { Type III Sum of } \\
\text { Squares }\end{array}$ & df & Mean Square & F & $\mathbf{p}$ & $\begin{array}{c}\text { Partial Eta } \\
\text { Squared }\end{array}$ \\
\hline Corrected Model & $1676.786 \mathrm{a}$ & 21 & 79.847 & 1.868 & .012 & .104 \\
Intercept & 62520.967 & 1 & 62520.967 & 146.3 & $<.001$ & .812 \\
Gender & 3.838 & 1 & 3.838 & .090 & .765 & $<.001$ \\
Grade & 138.005 & 2 & 69.003 & 1.614 & .201 & .009 \\
Age & 311.137 & 4 & 77.784 & 1.820 & .125 & .021 \\
Types of schools & 231.863 & 1 & 231.863 & 5.425 & .02 & .016 \\
gender * types of schools & 66.326 & 1 & 66.326 & 1.552 & .214 & .005 \\
Error & 14447.189 & 338 & 42.743 & & & \\
Total & 556919.000 & 360 & & & & \\
Corrected Total & 16123.975 & 359 & & & & \\
\hline \multicolumn{7}{c}{ a. R Squared $=.104$ (Adjusted R Squared $=.048)$} \\
\hline
\end{tabular}

Only values $>0$ are indicated in the table.

At the beginning of the school year, only the type of schools differentiated the students in their depression (see Table 6).

Table 7. General linear model of influence of gender, grade, age, and types of schools on students' depression at the end of the school year (main effects and interactions).

\begin{tabular}{lcccccc}
\hline \multicolumn{1}{c}{ Source } & $\begin{array}{c}\text { Type III Sum of } \\
\text { Squares }\end{array}$ & df & Mean Square & F & p & $\begin{array}{c}\text { Partial Eta } \\
\text { Squared }\end{array}$ \\
\hline Corrected Model & $1733.695 \mathrm{a}$ & 29 & 59.783 & 1.352 & .111 & .106 \\
Intercept & 161315.061 & 1 & 161315.061 & 364.7 & $<.001$ & .917 \\
Gender & 2.784 & 1 & 2.784 & .063 & .802 & $<.001$ \\
Grade & 93.124 & 3 & 31.041 & .702 & .552 & .006 \\
Age & 32.158 & 4 & 8.039 & .182 & .948 & .002 \\
Types of schools & 86.364 & 1 & 86.364 & 1.953 & .163 & .006 \\
gender * grade & 276.457 & 3 & 92.152 & 2.083 & .102 & .019 \\
gender * age & 351.113 & 4 & 87.778 & 1.985 & .097 & .023 \\
gender * types of schools & 28.008 & 1 & 28.008 & .633 & .427 & .002 \\
grade * types of schools & 147.077 & 3 & 49.026 & 1.108 & .346 & .010 \\
age * types of schools & 102.017 & 4 & 25.504 & .577 & .680 & .007 \\
gender * grade *types of schools & 260.882 & 1 & 260.882 & 5.898 & .016 & .018 \\
gender * age * types of schools & .006 & 1 & .006 & $<.001$ & .991 & $<.001$ \\
Error & 14595.805 & 330 & 44.230 & & & \\
Total & 561552.000 & 360 & & & & \\
Corrected Total & 16329.500 & 359 & & & & \\
\hline \multicolumn{1}{c}{ a. R Squared = .106 (Adjusted R Squared = .028) } & & & & & \\
\hline
\end{tabular}

Only values $>0$ are indicated in the table. 
OF PSYCHOLOGY

IN THE $21^{\text {st }}$ CENTURY

Vol. 9, No. 1, 2015

36

At the end of the school year, the gender, grade and the types of schools interacted to differentiate the students in their depression (see Table 7). The highest scores on depression had girls in 11th grade at schools of special education, followed by the girls in $9^{\text {th }}$ grade at schools of general education (see Table 8 ). The lowest scores on depression had girls in $10^{\text {th }}$ and $12^{\text {th }}$ grades at schools of special education, boys in $11^{\text {th }}$ grade at schools of special education, and boys in $10^{\text {th }}$ grade at schools of special education.

At the end of the school year, the gender, grade and the types of schools interacted to differentiate the students in their depression. There was a trend the boys in schools of special education to have the highest depression in 12th grade; the girls in schools of special education to have the highest depression in 11th grade; the boys and the girls in schools of general education to have the highest depression in 9 th grade (see Figure 1).

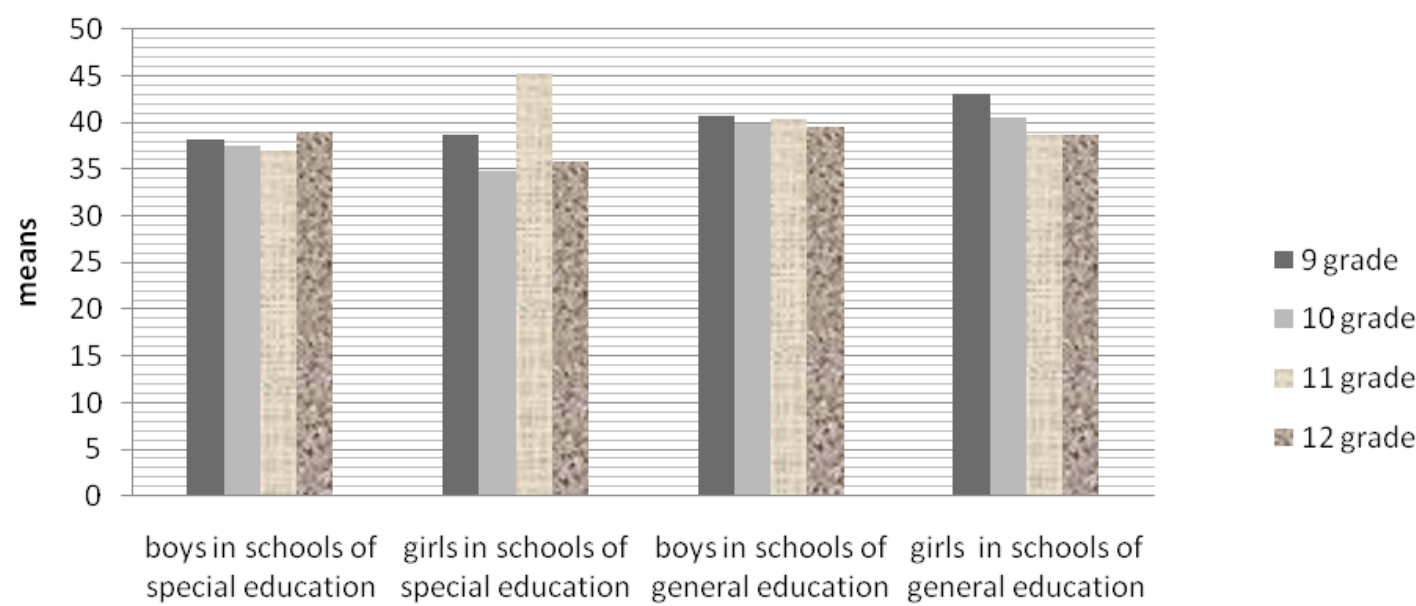

Figure 1: $\quad$ Mean level of depression at the end of the school year among secondary school students with different gender, grade and type of schools.

Table 8. Mean scores on depression of the secondary school students at the end of the school year, according to types of schools, gender and grade.

\begin{tabular}{ccccccc}
\hline \multirow{2}{*}{ Types of schools } & & \multicolumn{4}{c}{ Grade } \\
\cline { 3 - 6 } & & & 9 & 10 & 11 & 12 \\
\hline \multirow{2}{*}{ Schools of special education } & \multirow{2}{*}{ Gender } & Male & 38.139 & 37.467 & 36.971 & 38.975 \\
& & Female & 38.611 & 34.737 & 45.307 & 35.868 \\
\hline \multirow{2}{*}{ Schools of general education } & \multirow{2}{*}{ Gender } & Male & 40.750 & 39.875 & 40.400 & 39.500 \\
& & Female & 43.107 & 40.535 & 38.667 & 38.722 \\
\hline
\end{tabular}

Note: The highest mean scores on depression are bolded. The lowest mean scores on depression are in italic. 
Table 9. Correlation and Regression coefficients between Depression scores (dependent variable) and scores on Extraversion, Neuroticism, Psychoticism, and Social desirability (predictors) at the beginning of the school year.

\begin{tabular}{|c|c|c|c|c|c|c|}
\hline$R=.548 ; R^{2}=.3 ; F=30.355 ; p<.001$ & $\begin{array}{l}\text { Correlation } \\
\text { coefficients }\end{array}$ & $\begin{array}{l}\text { Depression at } \\
\text { the beginning of } \\
\text { the school year }\end{array}$ & $B$ & Beta & $T$ & $p$ \\
\hline \multirow{2}{*}{$\begin{array}{l}\text { Anxiety at the beginning of the } \\
\text { school year }\end{array}$} & $r$ & .301 & \multirow{2}{*}{.187} & \multirow{2}{*}{.153} & \multirow{2}{*}{3.207} & \multirow{2}{*}{.001} \\
\hline & $p$ & $<.001$ & & & & \\
\hline \multirow{2}{*}{$\begin{array}{l}\text { Extraversion at the beginning of } \\
\text { the school year }\end{array}$} & $r$ & -.258 & \multirow{2}{*}{-.259} & \multirow{2}{*}{-.13} & \multirow{2}{*}{-2.79} & \multirow{2}{*}{.006} \\
\hline & $p$ & $<.001$ & & & & \\
\hline \multirow{2}{*}{$\begin{array}{l}\text { Neuroticism at the beginning of the } \\
\text { school year }\end{array}$} & $r$ & .425 & \multirow{2}{*}{.417} & \multirow{2}{*}{.324} & \multirow{2}{*}{6.697} & \multirow{2}{*}{$<.001$} \\
\hline & $p$ & $<.001$ & & & & \\
\hline \multirow{2}{*}{$\begin{array}{l}\text { Psychoticism at the beginning of } \\
\text { the school year }\end{array}$} & $r$ & .318 & \multirow{2}{*}{.479} & \multirow{2}{*}{.263} & \multirow{2}{*}{5.485} & \multirow{2}{*}{$<.001$} \\
\hline & $p$ & .000 & & & & \\
\hline \multirow{2}{*}{$\begin{array}{l}\text { Social desirability at the beginning } \\
\text { of the school year }\end{array}$} & $r$ & -.008 & \multirow{2}{*}{.338} & \multirow{2}{*}{.086} & \multirow{2}{*}{1.822} & \multirow{2}{*}{.069} \\
\hline & $p$ & .883 & & & & \\
\hline
\end{tabular}

At the beginning of the school year, higher depression was related to higher anxiety, introversion, neuroticism, and psychoticism (see Table 9).

Table 10. Correlation and Regression coefficients between depression scores (dependent variable) and scores on Extraversion, Neuroticism, Psychoticism, and Social desirability (predictors) at the end of the school year.

\begin{tabular}{|c|c|c|c|c|c|c|}
\hline$R=.51 ; R^{2}=.26 ; F=24.844 ; p<.001$ & $\begin{array}{l}\text { Correlation } \\
\text { coefficients }\end{array}$ & $\begin{array}{l}\text { Depression } \\
\text { at the end of } \\
\text { the school } \\
\text { year }\end{array}$ & B & Beta & $T$ & $p$ \\
\hline \multirow{2}{*}{$\begin{array}{l}\text { Anxiety at the end of the school } \\
\text { year }\end{array}$} & $r$ & .370 & \multirow{2}{*}{.29} & \multirow{2}{*}{.24} & \multirow{2}{*}{4.861} & \multirow{2}{*}{$<.001$} \\
\hline & $p$ & $<.001$ & & & & \\
\hline \multirow{2}{*}{$\begin{array}{l}\text { Extraversion at the end of the } \\
\text { school year }\end{array}$} & $r$ & -.222 & \multirow{2}{*}{-.264} & \multirow{2}{*}{-.121} & \multirow{2}{*}{-2.486} & \multirow{2}{*}{.013} \\
\hline & $p$ & $<.001$ & & & & \\
\hline \multirow{2}{*}{$\begin{array}{l}\text { Neuroticism at the end of the } \\
\text { school year }\end{array}$} & $r$ & .237 & \multirow{2}{*}{.389} & \multirow{2}{*}{.286} & \multirow{2}{*}{5.808} & \multirow{2}{*}{$<.001$} \\
\hline & $p$ & $<.001$ & & & & \\
\hline \multirow{2}{*}{$\begin{array}{l}\text { Psychoticism at the end of the } \\
\text { school year }\end{array}$} & $r$ & .403 & \multirow{2}{*}{.212} & \multirow{2}{*}{.122} & \multirow{2}{*}{2.527} & \multirow{2}{*}{.012} \\
\hline & $p$ & $<.001$ & & & & \\
\hline \multirow{2}{*}{$\begin{array}{l}\text { Social desirability at the end of the } \\
\text { school year }\end{array}$} & $r$ & .034 & \multirow{2}{*}{.013} & \multirow{2}{*}{.004} & \multirow{2}{*}{.081} & \multirow{2}{*}{.936} \\
\hline & $p$ & .517 & & & & \\
\hline
\end{tabular}

At the end of the school year, higher depression was related again to higher anxiety, introversion, neuroticism, and psychoticism (see Table 10). These are the same correlations as at the beginning of the school year. 

OF PSYCHOLOGY IN THE $21^{\text {st }}$ CENTURY Vol. 9, No. 1, 2015 38

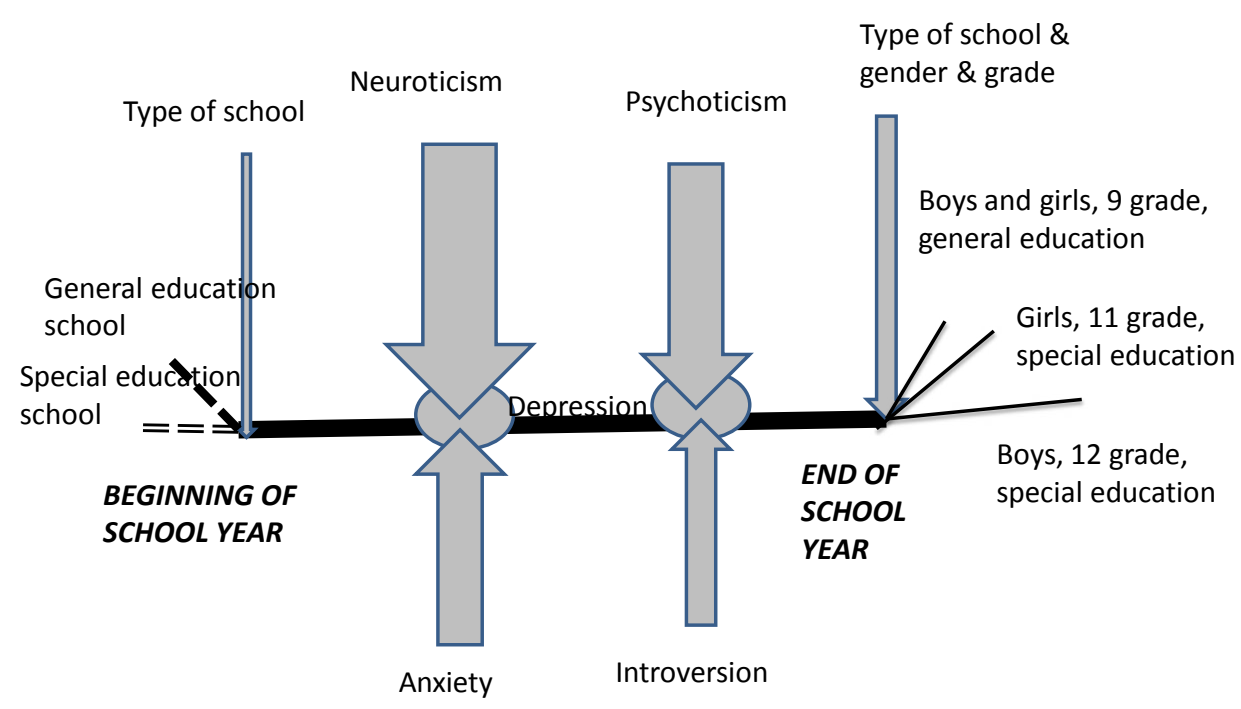

Figure 2: Model of dynamics of depression at upper school age in Bulgaria.

Figure 2 presents the dynamics of depression and its relationships with some personality and social determinants in secondary school students. This model resulted from the research findings. Every factor that was found to influence on secondary students' depression or to differentiate adolescents' depression was included in Figure 2. The dynamics of depression was presented on a continuum form the beginning to the end of the school year. Depression slightly increases from the beginning to the end of the school year being differentiated by the types of the schools at the beginning of the school year and by the interaction of the types of schools, gender and grade at the end of the school year.

\section{Discussion}

This study of dynamics of depression was based on the one hand on Developmental theories of dynamics of depression that relate depression to some vulnerable age groups (in this case adolescent age with each grade from $9^{\text {th }}$ to $12^{\text {th }}$ as a different age group). This study of dynamics of depression was based on the other hand on the theories that relate dynamics of depression to one or more factors that trigger depression in different stages of human life. The factors that were the focus of this study on dynamics of depression could be considered to a certain degree in the scope of psychosocial class theory of depression (Storck, 1999), because of the different cognitive, social and personal resources available at the beginning and the end of the school year.

The first hypothesis that depressive symptoms at the end of the school year would be more strongly expressed than at the beginning of the school year was not supported by the research findings. The studied students did not differ significantly in their depression scores at the beginning and at the end of the school year, but depressive scores at the end of the school year were slightly higher than at the beginning of the school year.

Secondary school students' anxiety also did not change between the beginning and the end of the school year (Petrova, 2013).

At the beginning of the school year, the students need some period to adapt to school environment after the long holidays. It is possible that the adaptation of the students in different types of schools to occur in different pace. The students in special education schools might have returned to school with more readiness and academic motivation than the students in general education schools who were slightly more depressed at the beginning of the school year. Enhanced motivation for study could be related to more positive attitude towards educational process. The students in the special schools could have more possibilities to study their preferred areas than the students in general education schools. 
During the school year, the workload does not seem to influence on the biggest part of secanxious. Anxiety and school successfulness (students' grade points) were not related (Petrova, 2013). Therefore, it is less probable low academic success to provoke higher anxiety among Bulgarian secondary students, and higher depression related to it. A further research on school success and depression should be conducted.

The second hypothesis that supposed that depression would be higher among more anxious students, introverts, with higher neuroticism, higher social desirability and lower psychoticism was confirmed partly. Both at the beginning and at the end of the school year, higher depression was related to higher anxiety, introversion, neuroticism, and psychoticism (not lower psychoticism). Higher psychoticism means loneliness, and distance in relationships (Paspalanov, Shtetinski \& Eysenck, 1984) that could be accompanied with depression. On the other hand, higher depression leads to alienation.

Depression and anxiety were comorbid in $28.7 \%$ of Chinese adolescents (Pan et al., 2013). The close relation between depression and anxiety was found also in Bulgarian adolescent sample. The positive correlation between depression and anxiety could be explained by the finding that depression and anxiety are due to the same genetic factors, but different environment specifies the type of the manifested disease (Kendler et al., 1992; McGue \& Irons, 2013).

No significant correlation was found between students' depression and social desirability. The striving for receiving other people's approval could maintain the interest in them, and also it could create some tension in the person who plays a role instead of being authentic. These two aspects of social desirability related to depression could balance each other.

The third hypothesis about some differences in students' depression levels depending on the grades and types of schools was supported partly. More students at schools of general education had mild depression than the students at schools of special education at the beginning of the school year, but there were not any significant differences in students' depression between the types of schools at the end of the school year. The secondary school students in both types of schools were adapted to the school environment and were interested in the upcoming summer holidays at the end of the school year. This finding suggests that secondary school students' depression could be more strongly related to extra-school factors than to school environment.

One possible explanation for differentiation of depression depending on the interaction of gender, grade and the types of schools at the end of the school year is that the students in general education schools are more disappointed with their type of school during the start of their education, but later they become more satisfied, while the students in special education schools are more exhausted at the end of their education in school. Besides, more students in special education schools plan to apply for university admission exams that have increased their workload.

The start of secondary school education in general schools is $9^{\text {th }}$ grade, while the students in special education schools in Bulgaria start their education in $8^{\text {th }}$ grade and their adaptation period to the type of school has already been finished during the period of conducting this study.

Gender could interact with the grade and the types of schools at the end of the school year, because there are some research findings that women are more often depressed than men (Marsh, 1989; Wehner \& Stoner, 2001). Females with depression outnumber males in adolescence and are equal in number during childhood (Allison et al., 2013). One more finding specified that urban Hispanic female adolescents had more depressive symptoms than urban Hispanic male adolescents (Robles-Pina, Defrance \& Cox, 2008). A specific trend in Bulgarian sample was that gender did not influence secondary students' depression independently, but in interaction with the grade and the types of schools.

The interaction between gender and grade was not statistically significant in China (Running, Ligon \& Miskioglu, 1999). No other studies have been focused on the effect of the types of schools for students' mental health. 


\section{Conclusions}

This study established a relatively stable dynamics of depression in Bulgarian secondary school students as Botcheva, Feldman and Leiderman (2002) did, but this study differentiated the role of the types of schools for depression at the beginning of the school year, and the interaction between gender, grade and types of school at the end of the school year, as well as some stable personality characteristics - anxiety, introversion, neuroticism and psychoticism - being constant determinants of depression during the whole school year.

The necessity of further studies that explain the influence of more factors on students' depression has been already indicated, for example concerning relationship between students' success and depression. Taking into account the peculiarities of the age group, it would be useful to be studied the link between some personality traits and depression, as well as the level of depression depending on peer relationships. Such findings would be important for psychoprophylaxis of depression. Early diagnostics and psychoprophylaxis of the depressive trends in personality development is important for adult mental health.

The model of depression in secondary school age could be useful for teachers and school psychologists, because it points out some risk periods in upper school age and some risk groups vulnerable to depression.

Longitudinal studies as this study have been conducted rarely, but they give the possibility to study the dynamics of development of one or more phenomena and to reveal some important factors that influence on them at different time periods. A longer time period for further longitudinal studies, their repetition more than twice, bigger sample size, including wider age scope, could be more useful in revealing the dynamics of depression.

Research of depression in adolescence permits to clarify the negative impact of depression on some cognitive processes. It is important dynamics of depression to be studied in adolescent age - the period of starting intimacy relationships and psychological vulnerability - in order to be developed some interventions for improving health and social functioning. Early detection of depression could facilitate treatment efforts among children and adolescents.

There are different possibilities for diminishing depression - group therapy, including cognitive behavioural therapy, music therapy, relaxation training; increasing knowledge about depression in the school curriculum, screening for depression in school age, school and family focused interventions; social internet use, social support; physical activity, etc. One possibility for prevention of depression is enhancing self-esteem, permitting independence and autonomy in making one's choices. Spending time on preferred activities could enhance positive emotions and diminish depression.

There are a lot of possibilities for influencing on dynamics of depression. This study indicates that interventions focused on diminishing anxiety, neuroticism (for example by meeting students' expectancies) and psychoticism (developing empathy and altruism), and increasing extraversion (better communication, social support) could be effective for diminishing depression throughout the whole school year. Motivating students, participating in more extra-curriculum activities related to the students' plans for further realisation in universities and workplace would be useful for diminishing students' depression as the experience of special education schools indicate.

\section{References}

Adler, A. (1997). Ponât prirodu čeloveka [Understanding human nature]. Sankt-Peterburg: Akademičeskij proekt.

Allison, V. L., Nativio, D. G., Mitchell, A. M., Ren, D., \& Yuhasz, J. (2013). Identifying symptoms of depression and anxiety in students in the school setting. The Journal of School Nursing, 30 (3), 165-172. doi:10.1177/1059840513500076

Altin, M., Harada, E., Schacht, A., Berggren, L., Walker, D., \& Dueñas, H. (2014). Does early improvement in anxiety symptoms in patients with major depressive disorder affect remission rates? A post-hoc analysis of pooled duloxetine clinic trials. Open Journal of Depression, 3, 112-123.http://dx.doi.org/10.4236/ ojd.2014.33015 
American Psychiatric Association. (1994). Diagnostic and statistical manual of mental disorders (4 $4^{\text {th }}$ edition). Washington, DC: American Psychiatric Association.

Beck, A., Rush, A., Shaw, B., \& Emery, G. (2003). Kognitivnaya terapiya depresii [Cognitive therapy of depression]. Sankt-Peterburg: Piter.

Bose, P. C., \& Neelakandan, R. (2013). A study on hospital anxiety and depression among aged groups. Indian Streams Research Journal, 3, 1-4.

Botcheva, L. B., Feldman, S. S., \& Leiderman, P. H. (2002). Can stability in school processes offset the negative effects of sociopolitical upheaval on adolescents' adaptation? Youth \& Society, 34 (1), 55-88. doi:10.1177/0044118X02034001003

Büchtemann, D., Luppa, M., Bramesfeld, A., \& Riedel-Heller, S. (2012). Incidence of late-life depression: A systematic review. Journal of Affective Disorders, 142, 172-179.

Chalise, H. N. (2014). Depression among elderly living in Briddashram (old age home). Advances in Aging Research, 3 (1), 6-11.

Cole, D. A., Sun-Joo, C., Martin, N. C., March, J. S., Compas, B. E., Rohde, P., Essex, M. J., Curry, J. F., Slattery, M. J., Youngstrom, E. A., Findling, R. L., Goodyer, I. M., Weissman, M., Hyde, J. S., Fore- hand, R., Felton, J. W., \& Maxwell, M. A. (2012). Are increased weight and appetite useful indicators of depression in children and adolescents? Journal of Abnormal Psychology, 121, 838-851.

Creative Research Systems (2012). Sample size calculator. Retrieved in 2015, from http://www.surveysystem. com/sscalc.htm

DeFronzo Dobkin, R., Panzarella, C., Alloy, L. B., Cascardi, M., Truesdell, K., \& Gara, M. (2007). Assessing an interpersonal-cognitive risk factor for depression: Preliminary validation of the Social Feedback Questionnaire. Journal of Social and Personal Relationships, 24 (5), 765-780. doi:10.1177/0265407507081465

Horney, K. (1997). Nevroz I lichnostnii rost. Borba za samoosushtestvlenie [Neurosis and human growth: The struggle toward self-realization]. Sankt-Petersburg: Vostochno-Evropeiskii Institut Psihoanaliza I BSK.

Horney, K. (2002). Samoanaliz [Self-analysis]. Moscow: Eksmo-press.

Huang, J. P., Xia, W., Sun, C. H., Zhang, H. Y., \& Wu, L. J. (2009). Psychological distress and its correlates in Chinese adolescents. The Australian and New Zealand Journal of Psychiatry, 43 (7), 674-681. doi: $10.1080 / 00048670902970817$

Jafari, F., Yousefi, Z., \& Manshaee, G.-R. (2014). Mothers characters and adolescence depression. Open Journal of Depression, 3, 45-51. http://dx.doi.org/10.4236/ojd.2014.32010

Joe, S., Joe, E., \& Rowley, L. L. (2009). Consequences of physical health and mental illness risks for academic achievement in grades K-12. Review of Research in Education, 33 (1), 283-309. doi:10.3102/0091732X08327355

Johanson, G. A., \& Brooks, G. P. (2010). Initial scale development: Sample size for pilot studies. Educational and Psychological Measurement, 70 (3), 394-400. doi:10.1177/0013164409355692

Joules, N., Williams, D.M., \& Thompson, A.W. (2014). Depression in resident physicians: A systematic review. Open Journal of Depression, 3, 89-100. http://dx.doi.org/10.4236/ojd.2014.33013

Kendler, K. S., Neale, M. C., Kessler, R. C., Heath, A. C., \& Eaves, L. J. (1992). Major depression and generalized anxiety disorder: Same genes, (partly) different environments. Archives of General Psychiatry, 49 (9), 716-722.

Klein, M. (1935). K voprosu o psihogeneze maniakalno-depresivniih sostoyanii [A contribution to the psychogenesis of manic-depressive states]. In Sbornik statii [Collection of papers]. Retrieved in May 2015, from http://www.klex.ru/9qx

Klein, M. (1940). Pechal i maniakalno depresivnie sostoyaniya [Mourning and its relation to manic-depressive states]. In Sbornik statii [Collection of papers]. Retrieved in May 2015, from http://www.klex.ru/9qx

Kokoshkarova, A. (1984). Psihologichno izsledvane na lichnostta v klinichnata praktika [Psychological study of personality in clinical practice]. Sofia: Meditsina I Fizkultura. 
OF PSYCHOLOGY

IN THE $21^{\text {st }}$ CENTURY Vol. 9, No. 1, 2015

Lee, G., McCreary, L., Kim, M. J., Park, C. G., Jun, W. H., \& Yang, S. (2012). Depression in low-income elementary school children in South Korea: Gender differences. The Journal of School Nursing, 29 (2), 132-141. doi:10.1177/1059840512452887

Leserman, J., \& Koch, G. (1993). Review of self-report depression and anxiety measures. Drug Information Journal, 27 (2), 537-548. doi:10.1177/009286159302700245

Leslie, L. A., \& Cook, E. T. (2015). Maternal trauma and adolescent depression: Is parenting style a moderator? Psychology, 6, 681-688. http://dx.doi.org/10.4236/psych.2015.66066

Marsh, K. L. (1989). Depression and attributional complexity. Personality and Social Psychology Bulletin, 15 (3), 325-336.

McGue, M., \& Irons, D. E. (2013). Etiology. In B. S. McCrady \& E. S. Epstein (Eds.), Addictions: A comprehensive guidebook (pp. 36-72). New York: Oxford.

McWilliams, N. (2011). Psychoanalytic diagnosis (Second edition): Understanding personality structure in the clinical process. Oxford: The Guilford Press.

Mental Health America (2013). Depression: What you need to know. Clinical depression is a common, real and treatable illness. Retrieved in May 2015, from http://www.mentalhealthamerica.net/conditions/depression

Mikolajczyk, R. T., Maxwell, A. E., El Ansari, W., Naydenova, V., Stock, C., Ilieva, S., Dudziak, U., \& Nagyova, I. (2008). Prevalence of depressive symptoms in university students from Germany, Denmark, Poland and Bulgaria. Social Psychiatry and Psychiatric Epidemiology, 43 (2), 105-112. doi:10.1007/s00127007-0282-0

Millard, C. (2013). Making the cut: The production of "self-harm" in post-1945 Anglo-Saxon psychiatry. History of the Human Sciences, 26 (2), 126-150. doi:10.1177/0952695112473619

Min, S. (2002). Mixed Rasch modeling of the self-rating depression scale. Incorporating latent class and Rasch rating scale models. Educational and Psychological Measurement, 67 (2), 280-299.

Mojs, E., Warchol-Biederman, K., \& Samborski, W. (2012). Prevalence of depression and suicidal thoughts amongst university students in Poznan, Poland, preliminary report. Psychology, 3 (2), 132-135. doi:10.4236/psych.2012.32020

Molzon, E. S., Hullmann, S. E., Eddington, a. R., \& Mullins, L. L. (2011). Depression, anxiety, and healthrelated quality of life in adolescents and young adults with allergies and asthma. Journal of Asthma \& Allergy Educators, 2 (6), 288-294. doi:10.1177/2150129711416501

Moreno, M. A., Jelenchick, L. A., \& Kota, R. (2013). Exploring depression symptom references on Facebook among college freshmen: A mixed methods approach. Open Journal of Depression, 2 (3), 35-41. doi:10.4236/ojd.2013.23008

Morley, D., \& Jenkinson, C. (2012). The importance of recognising depression in adolescents affected by parental illness. Psychology, 3 (Special Issue), 756-757.

Mozumdar, A., \& Roy, S. K. (2010). Depression in adult males with lower extremity amputation and its biosocial correlates. Health, 2 (8), 878-889. doi:10.4236/health.2010.28131

National Statistical Institute of Republic of Bulgaria. (2014). Schools, classes, teaching staff, students and graduates in general and special schools by statistical zones, statistical regions, districts and municipalities in 2013/2014 school year. Retrieved in 2015, from http://www.nsi.bg/en/content/4886/schools-classesteaching-staff-students-and-graduates-general-and-special-schools

Omran, M. P. (2011). Relationships between cognitive emotion regulation strategies with depression and anxiety. Open Journal of Psychiatry, 1 (3), 106-109. doi:10.4236/ojpsych.2011.13015

Pan, X., Liu, W., Deng, G., Liu, T., Yan, J., Tang, Y., Dong, W., Cui, Y., \& Xu, M. (2013). Symptoms of posttraumatic stress disorder, depression, and anxiety among junior high school students in worst-hit areas 3 years after the Wenchuan earthquake in China. Asia Pacific Journal of Public Health, 20 (10), 1-10. doi:1010539513488625

Paspalanov, I., Shtetinski, D., \& Eysenck, S. (1984). Bulgarska adaptatsia na lichnostnia vaprosnik na Hans Eysenck [Bulgarian adaptation of Eysenck Personality Questionnaire]. Psihologia, 11 (5), 279 - 293. 
Patten, S. B., Gordon-Brown, L., \& Meadows, G. (2010). Simulation studies of age-specific lifetime major depression prevalence. BMC Psychiatry, 10, 85-100

Petrova, V. (2013). Trevojnost I uchebna uspevaemost $\mathrm{v}$ nachaloto na gorna uchilishtna vazrast [Anxiety and school successfulness at the beginning of upper school age]. In I. Asenova, S. Stoyanova, I. Peneva, H. Arabadzhieva \& I. Andonova (Eds), Psychology - traditions and perspectives (Vol. 1, pp. 273-278). Blagoevgrad: SWU "Neofit Rilski".

Phanthavong, P., Naphayvong, P., \& Reinharz, D. (2013). Depression among last-year high school students in Vientiane, capital city of Lao PDR. Asia Pacific Journal of Public Health, 20 (10), 1-4. doi: 1010539513489135

Phillips, W. J., \& Hine, D. W. (2012). Exploring the factor structure of implicit and explicit cognitions associated with depression. Assessment, 20 (4), 474-483. doi:10.1177/1073191112437595

Price, J. (2009). Darwinian dynamics of depression. The Australian and New Zealand Journal of Psychiatry, 43 (11), 1029-1037. doi:10.3109/00048670903308611

Riemann, F. (1961). Onnovni formi na strah (Edna dalbinno-psihologicheska studia) [Basic forms of fear (A depth psychology study)]. Retrieved in May 2015, from http://chitanka.info/text/8154-osnovni-formina-strah\#text-links

Robles-Pina, R. A., Defrance, E., \& Cox, D. L. (2008). Self-Concept, early childhood depression and school retention as predictors of adolescent depression in urban Hispanic adolescents. School Psychology International, 29 (4), 426-441. doi:10.1177/0143034308096434

Running, D. M., Ligon, J. B., \& Miskioglu, I. (1999). Reliability and factor structure of the Chinese version of the Depression Self-Rating Scale. Journal of Composite Materials, 33 (10), 928-940. doi:0803973233.

Salmela-Aro, K., Aunola, K., Saisto, T., Halmesmaki, E., \& Nurmi, J. E. (2006). Couples share similar changes in depressive symptoms and marital satisfaction anticipating the birth of a child. Journal of Social and Personal Relationships, 23 (5), 781-803. doi:10.1177/0265407506068263.

Sarkohi, A., Frykedal, K. F., Forsyth, H. H., Larsson, S., \& Andersson, G. (2013). Representations of the future in depression - A qualitative study. Psychology, 4 (4), 420-426. doi:10.4236/psych.2013.44059.

Shafi, A. M. A. \& Shafi, R. M. A. (2014). Cultural Influences on the presentation of depression. Open Journal of Psychiatry, 4, 390-395. http://dx.doi.org/10.4236/ojpsych.2014.44045.

Shavers, C. A. (2014). Commentary: Emotional problems and depression among children and adolescents in today's society. Open Journal of Depression, 3, 74-87. http://dx.doi.org/10.4236/ojd.2014.32012.

Shittu, R. O., Odeigah, L. O., Issa, B. A., Olanrewaju, G. T., Mahmoud, A. O., \& Sanni, M. A. (2002). Association between depression and social demographic factors in a Nigerian family practice setting. Open Journal of depression, 3 (1), 18-23. http://dx.doi.org/10.4236/ojd.2014.31006.

Skues, J. L., Banagan, R. F., \& Wise, L. Z. (2014). Facebook and diagnosis of depression: A mixed methods study. Social Networking, 3, 187-195. http://dx.doi.org/10.4236/sn.2014.34023.

Song, S. J., Ziegler, R., Arsenault, L., Fried, L. E., \& Hacker, K. (2011). Asian student depression in American high schools: Differences in risk factors. The Journal of School Nursing, 27 (6), 455-462. doi:10.1177/1059840511418670.

Stanners, M., Barton, C., Shakib, S., \& Winefield, H. (2013). The prevalence of depression amongst outpatients with multimorbidity. Health, 5 (4), 805-810. DOI: 10.4236/health.2013.54106.

Storck, L. E. (1999). Social class divisions in the consulting room: A theory of psychosocial class and depression. Groups analysis, 31, 101-115.

Tezvaran, Z., Akan, H., \& Zahmaciog, O. (2012). Risk of depression and anxiety in high school students and factors affecting it. Health MED, 6, 3333-3339.

Thorsteinsson, E., Ryan, S. M., \& Sveinbjornsdottir, S. (2013). The mediating effects of social support and coping on the stress-depression relationship in rural and urban adolescents. Open Journal of Depression, $2(1), 1-6$.

Thurber, S., Snow, M., \& Honts, C. R. (2002). The Zung Self-Rating Depression Scale: convergent validity and diagnostic discrimination. Assessment, 9 (4), 401-405. doi:10.1177/1073191102238471. 
OF PSYCHOLOGY

IN THE $21^{\text {st }}$ CENTURY

Vol. 9, No. 1, 2015

44

Wang, K. T., Yuen, M., \& Slaney, R. B. (2009). Perfectionism, depression, loneliness, and life satisfaction. A study of high school students in Hong Kong. The Counseling Psychologist, 37 (2), 249-274.

Wehner, J. S., \& Stoner, S. C. (2001). Tools and techniques for evaluating Depression. Journal of Pharmacy Practice, 14 (6), 448-452. doi:10.1106/7Y0J-RUKC-P7GV-V1UV.

Whisman, M. A., Judd, C. M., Whiteford, N. T., \& Gelhorn, H. L. (2012). Measurement invariance of the Beck Depression Inventory-Second Edition (BDI-II) across gender, race, and ethnicity in college students. Assessment, 20 (4) 419-428. doi:10.1177/1073191112460273.

Wood, B. M., Nicholas, M. K., Blyth, F., Asghari, A., \& Gibson, S. (2010). The utility of the short version of the depression anxiety stress scales (DASS-21) in elderly patients with persistent pain: Does age make a difference? Pain Medicine, 11, 1780-1790.

World Health Organization. (1992). The ICD-10 classification of mental and behavioural disorders. Retrieved in March 2015, from http://www.who.int/classifications/icd/en/bluebook.pdf.

Xu, X., Liang, J., Bennett, J. M., Quiñones, A. R., \& Ye, W. (2010). Ethnic differences in the dynamics of depressive symptoms in middle-aged and older Americans. Journal of Aging and Health, 22 (5), 631-652. doi:10.1177/0898264310370851.

Yang, Y., \& George, L. K. (2005). Functional disability, disability transitions, and depressive symptoms in late life. Journal of Aging and Health, 17 (3), 263-292. doi:10.1177/0898264305276295.

Zung, W. W. K. (1972). A cross-cultural survey of depressive symptomatology in normal adults. Journal of Cross-Cultural Psychology, 3 (2), 177-183.

Advised by Laima Railiene, Siauliai University, Lithuania

Received: April 02, 2015

Accepted: June 18, 2015

Stanislava Stoyanova

PhD, Professor, South-West University "Neofit Rilski”, Blagoevgrad,

Bulgaria.

E-mail: avka@abv.bg

Website: https://www.swu.bg/?lang=en 